\title{
Creativity in Greek Music Curricula and Pedagogy: An Investigation of Greek Music Teachers' Perceptions
}

\author{
Dimitrios Zbainos ${ }^{1}$, Ariadni Anastasopoulou ${ }^{2}$ \\ ${ }^{1}$ Harokopio University, Athens, Greece \\ ${ }^{2}$ National and Kapodistrian University, Athens, Greece \\ Email: zbainos@hua.gr
}

Received December $21^{\text {st }}, 2011$; revised January $16^{\text {th }}, 2012$; accepted February $5^{\text {th }}, 2012$

\begin{abstract}
Creativity's enhancement through education has been widely discussed and promoted in Greece, especially in the past few decades. In the music domain, teaching philosophy and practice seem to focus on ways that can encourage children to learn and apply their knowledge through creative music activities. This paper reports on the outcomes of a study undertaken with 112 general music teachers of different ages and scientific backgrounds, who teach in 235 primary and secondary schools in Greece. Being the first time that such research is being conducted in Greece, the main aim of the study was to reveal how Greek music teachers think, feel about, and influence pupils' creativity and the teaching conditions that may enhance or inhibit it. It is believed that such a study may contribute to the development of creativity enhancement projects through music teaching. The findings suggest that creativity is associated by Greek music teachers with a natural gift that cannot be addressed in all students, and can only be partly taught in music classroom. They also indicate that teachers do not have an explicit understanding of music creativity as well as creativity assessment, since most of them tend to assess students' creative performance on the basis on non musical criteria (i.e. participation, eagerness, etc.). Results also show that creative musical activities are more often applied in primary education, while in secondary education they are successively replaced by music theory and history. Finally, teachers' negative views about the music curriculum, textbooks and number of teaching hours are identified. Such findings lead to suggestions for numerous changes in music teachers' education, establishing training in teaching for creativity as a fundamental priority.
\end{abstract}

Keywords: Music Creativity; Music Education; Greek Primary and Secondary Education

\section{Introduction}

Creativity has been defined as the ability to produce work that is novel, and appropriate (Sternberg, Kaufman, \& Pretz, 2002) which, according to Kaufman \& Baer (2004) is endorsed by many theorists. For instance, Lubart \& Guignard (2004) define it "as the capacity to produce novel, original work that fits with task constraints" (p. 43). According to the report of NACCCE (1999) "all people are capable of creative achievement in some area of activity, provided that the conditions are right and they have acquired the relevant knowledge and skills" (Chapter 2, par. 27). This view is close to the current research orientation that focuses on any person's creativity, which develops in the social system rather than within one person, and whose existence does not depend solely on its connection to new original products (Craft, 2005). Creativity is an innate characteristic of all humans, but a combination of circumstances is needed for it to emerge. Everyone has creative potential, because everyone can understand and appreciate her/his experiences (Runco, 2003, 2006). The necessary elements may be inherent in some people, while some other need help, encouragement and support to operate creatively. Especially children whose creative potential has not been expressed yet, are the ones who need education and the creative conditions that education may offer to them. Sharp (2004) as well as a number of other researchers (e.g. Amabile, 1996; Cropley, 1997; Horng, Hong, ChanLin, Chang, \& Chu, 2005; Lindström, 2006; Mahboub, Portillo, Liu, \& Chandraratna, 2004) think that children's creativity can be enhanced in education in three aspects: The creative learning environment, the creative educators and creative teaching.

In the past few decades, creativity has been one of the primary concerns of educational policy. In recent years especially, an intense trend in the educational planning of many countries for the recognition of creativity and its inclusion in the aims and the objectives of the curricula (Sharp, 2004), may be observed. Amid the rapid social changes, the competition of the economies, and the continuous technological achievements, it has been gradually realized that schools need to produce people capable of innovation and originality. This comprised the beginning of the attempt for the encouragement of creativity in schools (Cropley, 1997).

Many states since then, with Greece among them, have attempted to change their curricula, often focusing on the development of creativity in education. In the Greek educational curriculum, it is mentioned that "the aim is to contribute to the overall harmonic and balanced development of the cognitive pscycho-physiological abilities of the pupils, so that, regardless of their gender and origin, they are able to develop into fully grown personalities and to live creatively; one of the basic principles which should be promoted through all educational subjects, is according to the Greek Ministry of Education (YPEPTH, 2003) the ability for creative conception.

\section{Creativity in Music Education}

Creativity related to the art of music is still covered with mystery. Music is a phenomenon which cannot be experientially 
isolated, (Williamon, Thomson, Lisboa, \& Wiffen, 2006). Even composers, who have experienced and are familiar with the creative process find it hard to describe with clarity (Haroutounian, 2002; Lapidaki, 2007). The difficulty of the definition and the exact description of music creativity however, should in no case dispute its existence and importance. Some researchers, attempting to define the meaning of music creativity, have described a process which, according to Webster (2002) is active, constructed and aiming at the production of something which is new to the person. Gordon (1988) argues that the person, consciously or unconsciously, organizes known music constructs and materials in new or unknown ways. Others (Hickey \& Webster, 2001; Webster, 2002) claim that during the creative process people have to activate both divergent and convergent thinking, as they have to conceive many musical ideas and then to select some of them and combine them such that they make music sense.

The conception of Csikszentmihalyi \& Custodero (2002) for the term music creativity is broader. They argue that it may appear in a number of human music expressions, such as the expression of a young child who produces spontaneous melodies and rhythms, or the conversion of an object into a musical instrument. The active relationship of people with their internal and external world, at the emergence of creativity, is stressed by Reybrouck (2006), who describes musical creativity beyond the narrow limits of composition and performance, as "coping with the sonic world" (p. 42). Besides, since people are in constant interaction with their environment, Haroutounian (2002) mentions that music creativity is the creative process of the communication of ideas and feelings through sounds, "the creative interpretation" as she names it.

Although the above definitions emphasize different elements of music creativity, they converge on the fact that it concerns an "interactive relationship" of a person with the sound, by which the person goes through some cognitive processes, either consciously with a specific aim in a predefined framework, or not. Odena \& Welch (2009) note that the term "creativity" is used in music education statutory guidelines in two different ways: a. describing composition/improvisation activities and b. highlighting the value of creativity as a desirable "thinking style". Therefore, although composition and improvisation still remain the main music creative activities, pupils' creativity can be expressed by a large number of other music activities such as performance, experimentation with musical instruments and sounds, as well as listening and exploring different sound sources (Koutsoupidou \& Hargreaves, 2009).

In past decades, important theories and models were developed to discuss music creativity and the framework in which it appears and develops (Csikszentmihalyi, 1996; Elliott, 1995; Sheridan \& Byrne, 2002; Swanwick, 1979; Webster, 1992, 1994, 2002, 2003). Researchers have been concerned with the processes by which people - and especially pupils - engage in musical creative activities of composition (e.g. Burnard, 2006; Burnard \& Younker, 2004) and improvisation (e.g. Kratus, 1995; Tafuri, 2006). Although music curricula worldwide tend to encourage creative teaching, there is evidence that teachers do not adopt creative child-centered practices (Koutsoupidou, 2010). The role of educators therefore as implementers of the curricula is crucial in creative teaching, especially in music teaching.

The term creative teacher implies that it is the teacher who reinforces and promotes the creativity of his/her pupils (Craft, 1997). This effort is continuous, everyday and flexible to modifications depending on the existing circumstances. Sternberg,
(Sternberg, 2003; Sternberg \& Grigorenko, 2004) defined creative teachers as the ones who encourage their pupils to create, invent, discover, imagine what would happen if, suppose that, and foresee. Teachers who can develop pupils' creativity are those who first of all identify the creative skills of pupils, (Jeffrey \& Craft, 2004), the factors that affect them, and the ways by which they can intervene so that they can be improved. Teacher understanding and valuing of creativity is a necessary condition for recognizing pupils' creative abilities and therefore generating the conditions which are necessary for their development (Cropley, 2001).

The acceptance of pupils' creative elements leads to an adoption of relevant teaching approaches and to the formation of school classes, in which mistakes, doubts, curiosity, free expression of ideas, and non expected answers by pupils are all accepted (Cropley, 2001). It is also essential that teachers themselves manifest characteristics of creative persons, such as: drawing satisfaction from the nature of their work and not only from the financial income or any distinctions it may provide; that is, to be motivated by intrinsic and not extrinsic motivation; to be easily susceptible to external feelings; to express their thoughts and ideas easily (Horng et al., 2005); to look for ways, means and materials; to plan interesting teaching and creative experiences for their pupils (Sharp, 2004) taking care, at the same time, that their creative personalities do not to overshadow the initiatives and efforts of their pupils (OFSTED, 2003).It is also part of teachers' work to use the appropriate strategies, so that they are the accommodators of learning, the co-operators and co-creators (Dineen \& Collins, 2005), as well as the classroom managers where the strict hierarchy of traditional teaching is absent and all views are freely heard (Belkin, 2002). It is important, however, that by no means, in the name of an ill-defined creativity, to overlook the quality of learning (Sternberg, 2003). Creative teachers' curiosity, willingness to explore and spiritual flexibility, all consist of a continuity of the secure subject knowledge and the constant knowledge renewal, and cannot-nor should they-be separated, because in such a way creativity loses its essence (OFSTED, 2003). Teaching that supports the development of the imagination and creativity requires teachers to position themselves off-center and to promote learning through activities that children choose themselves (Burnard, 2006).

Finally, as far as pupils' assessment is concerned, the teacher attitude that supports pupils' creativity, is the provision of constant and immediate feedback, the systematic use of formative assessment in the classroom, the training of pupils in peer assessment practices, and the motivation of teachers and pupils to do self-assessments (Cropley, 2001). Creative activities need quailtative assessments, in which the emphasis is placed not that much on the final product or the final performance, but rather on the process that has led to it (Runco, 2003, 2006). In any case, there is a need for clear criteria and methodology for the assessment of creative activities which derive from teachers' knowledge of pupils' musical perception, as well as from creative activities (Wiggins, 2002). Teachers should know the most appropriate activities for each occasion, so that they choose the ones which correspond to pupils' needs, interests, and levels (J. Wiggins, 1999).The main music creative activities are composition and improvisation, but pupils' creativity can be expressed by a large number of other music activities such as performance, experimentation with musical instruments and sounds, as well as the exploration of sound sources.

Music teachers' beliefs about creativity have not been invest- 
tigated extensively. Odena (2001) studied music teachers' views about creativity and its expression in music teaching. He was led to the conclusion that teachers interpret creativity in a personal and subjective way. In a later study (Odena, 2006), attempting to find the factors that differentiate teachers' views, he concluded that they (the views) were affected significantly more by the type of their music studies (university, conservatory, etc) than their educational studies and their years of experience in education. It seems, therefore, that their sense of creativity is rather vague, and hard for teachers to define. In a later study, Odena and Welch demonstrated that teachers' beliefs about students' creativity were affected by their own teaching experiences that is, their own musical and teacher education, as well as professional training. The more such experiences teachers had, the more able they were to recognize and appreciate the different ways students approach a composition assignment. This study also supported his earlier finding (Odena, 2001) regarding the subjective and personal interpretation of student creativity by teachers.

In Greece, the subject of music is taught once a week in the last four grades of the Primary school (3rd, 4th, 5th, 6th) and in all three grades of the lower Secondary School (Gymnasion). Specialized music schools also teach in secondary education, but are not the focus of the present study. Music teachers may be graduates of one of the four Music Departments of Greece's State Universities, or alternatively, they may hold certificates of study (theoretical or of musical instrument ${ }^{1}$ ) from private Conservatories or Music Schools. The selection of qualified teachers for education in recent years happens through a written examination that takes place every two years.

The educational material is designed by the Institute of Pedagogy of the Greek Ministry of Education. In Primary education music textbooks (student book, workbook, teacher book) were first introduced in the academic year 2007-2008, while in secondary education, the existing textbook (student book) has not been modified, renewed or replaced since first being introduced in 1985. The music curricula, on the other hand, were modified in 2003, without however, the simultaneous introduction of new teaching material. Criticism has been launched at the position of creativity in the music curricula; although it is often mentioned as one of the primary aims of music teaching (YPEPTH, 2003), a clear definition of it is not given.

The present study attempted to investigate music teachers' perceptions about the role of creativity and creative music activities in Greek compulsory education, as such research has never been conducted before in Greece.

The particular research questions it aimed to answer were:

How frequently do Greek music teachers implement creative activities?

What are Greek music teachers' beliefs about the role of creativity in teaching?

How do Greek music teachers understand music creativity?

What are Greek music teachers' efficacy beliefs about teaching and assessing pupils' creativity?

\section{Method}

\section{Sample}

The sample consisted of 112 music teachers, (graduates of

${ }^{1}$ In Greek private conservatories, one can hold degrees in theoretical studies (Degree in Odiki, Harmonic Theory, Counterpoint, Fugue and Diploma in Composition) and/or instrumental studies (first degree-ptychion and second degree-diploma in a certain musical instrument).
Music Departments of University or of Private Conservatories), teaching in 232 primary and secondary schools. Eighty nine participants $(79.5 \%)$ were female and $23(20.5 \%)$ male. Most of them $(60.7 \%)$ were under 40 years old. More than two thirds of the sample $(68.8 \%)$ had a University degree in Music, as they had graduated from private Conservatories. $31.3 \%$ of participants had a first degree in Music and 5 of them held a master degree. Two had earned PhDs. Most of the participants (90.2\%) held a music degree from a private music conservatory. The majority of music degrees of all of the teachers (University graduates and non graduates) were in Harmonic Theory and Counterpoint (57 and 61\% respectively). Less than half of the participants had a Degree in Counterpoint (23.2\%) and a Diploma in Composition (23.2\%). No important differences were observed in age and years of professional experience distribution. Nevertheless, 6 out of 10 respondents belonged to the age group "31 - 40 years old". The highest percentage $(55.4 \%)$ of the music teachers, at the time of the study, taught in Primary education, while $46 \%$ in Lower Secondary School (Gymnasium). Teachers who belonged to the "above 40" age groups, taught mainly in secondary education (58.2\%), while younger ones ("40 or under") taught in primary education. This differentiation reflects the fact that the subject of Music has only recently been included in the Primary School Curricula, while in Secondary Education it has been taught for several decades.

Music teachers in Greece are usually obliged to work in more than one school, as music lessons are taught only once a week in every class. In primary education, where schools have a small number of classes, half of the music teachers reported that they were required to teach in three different schools, while most of teachers in Gymnasium (58.7\%) taught music in one school and $40 \%$ of them in two schools. Eleven per cent of teachers in primary schools had to teach in four or even in five schools.

\section{Research Instrument}

In accordance with the research questions, an anonymous questionnaire was administered to the music teachers of the sample. It included both closed- and open-ended questions. Details of the format and the content of the items will be provided in the next section together with the results. The internal consistency of the closed ended questions was satisfactory (Cronbach's $\alpha=.84$, explaining $70.56 \%$ of the total variance). The questionnaires were delivered to music teachers of Greek primary and secondary schools from September to December 2007. Of 148 questionnaires, $112(75.68 \%)$ were returned completed.

\section{Results}

\section{Implementation of Music Creative Activities}

The first part of the questionnaire included fourteen statements referring to music activities that may occur in a music lesson. The first six of them described general music activities (singing, listening, music analysis, performance, music theory/history, music dictation), and the rest eight statements referred to creative music activities (composition, improvisation, experimentation, instrumentation, all with instruments or/and musical sources). Teachers were asked to mark the frequency of activities' employment in their music class. Answers ranged from 1 (never employed) to 5 (employed in every lesson). The results showed that teaching time in Primary school was mainly devoted to singing $(\mathrm{M}=4.11, \mathrm{SD}=0.749)$ and instrumental performance, 
solo or orchestra $(\mathrm{M}=3.45, \mathrm{SD}=1.097)$. Teaching in secondary schools, on the contrary, included music theory and history in almost every lesson $(\mathrm{M}=4.22, \mathrm{SD}=0.987)$ and quite often singing $(\mathrm{M}=3.72, \mathrm{SD}=1.089)$ and listening and evaluating $(\mathrm{M}$ $=3.63, \mathrm{SD}=0.853)$. Music dictation was the least implemented general music activity in both primary $(\mathrm{M}=1.85, \mathrm{SD}=0.786)$ and secondary $(\mathrm{M}=1.89, \mathrm{SD}=1.120)$ music teaching. Additionally, it was found that singing and performing were replaced in secondary education by music theory and history. The second set, consisting of seven questions, was related to creative music activities, such as composition, improvisation, instrumentation and improvisation. Creative activities were less frequently employed in all educational levels. No participant reported that s/he employed any creative activity "very often" (value 4) or "in every lesson" (value 5). All means were below the middle value "sometimes" (3). The least implemented creative music activeties seemed to be composition, either vocal or instrumental. Overall, creative music activities appeared to be less frequently implemented than general music activities, such as singing or music audition. Composition seemed to be the least frequently implemented activity both in primary and secondary education. The years of professional experience appeared to differentiate music teaching. The mean frequency of creative music activities in teaching was found to be significantly higher in teachers with less professional experience, than in more experienced ones, who appeared to teach mainly music theory and history $(\mathrm{F}(110)$ $=11.829, p=.000$ ). A post-hoc analysis (Tukey's b) showed that significant differences lie mainly between groups with experience "1 - 5 years" and "more than 20 years".

Greek music teachers appeared to differ significantly with regard to the instrument degree they held $(\mathrm{F}(110)=3.51, p$ $<.05$,). The post-hoc analysis (Tukey's b) showed that those with no instrument degree tended to include composition in their teaching significantly less than teachers who possessed a first or a second degree in a musical instrument.

\section{Teachers' Beliefs on the Role of Creativity in Teaching}

According to the answers teachers gave to an open-ended question regarding the role of creativity in teaching, it seemed that they tended to believe that creativity is an innate characteristic which can be promoted only up to a certain degree through education, since it cannot be taught to all children. What teaching can do is to motivate pupils to be creative. About one in three participants $(30.8 \%)$ thought that it can be promoted with proper methodology, while $4.4 \%$ of the teachers reported the belief that creativity is a solely personal attribute that cannot be taught.

\section{Music Teachers' Understanding of Music Creativity}

Participants' understanding of the manifestations of creativity was investigated through four statements (two describing creative situations and two non creative). They were presented to music teachers, asking them to mark their opinion on a fivepoint Likert type agreement scale ( $1=$ "I strongly disagree" to 5 = "I strongly agree"). The main finding of this item is that a large percentage of teachers $(46.3 \%$ and $40.9 \%)$ seemed to perceive non creative situations as creative.

In the next open-ended question participants were asked to report a case in which pupils' creativity was manifested in music teaching. Most of them mentioned "rhythmic improvisation with percussion" (40\%) and "instrument construction" (15\%).
Pantomime, sound story and melodic improvisation in existing lyrics were also among most frequent answers. Interestingly, music composition was not mentioned at all.

\section{Music Teachers' Efficacy Beliefs about Teaching and Assessing Pupils' Creativity}

Participants expressed a high level of self-efficacy in teaching and assessing music creative activities on a five-point Likert type agreement scale.

Private conservatories' graduates appeared to feel significantly more efficacious in assessing composition than their colleagues who held a University degree $(\mathrm{t}(106)=3.189, p<.01)$.

Teachers were asked to name criteria they used for assessing creative responses to an open-ended question. The most commonly mentioned one was originality $(23.4 \%)$. Others, however, did not describe creative behaviors, but rather social skills, such as eagerness (18.2\%), co-operation (16.9\%) and pupil's effort (13\%). Imagination was mentioned in $11.7 \%$ of all answers, while $9 \%$ of music teachers reported that they assessed creativity taking into account the degree to which pupils follow given rules and directions. It is also worth stressing that 35 teachers $(31.2 \%)$ found it difficult to mention any specific assessment criteria.

This finding strengthens the idea that teachers did not have explicit ideas about what creativity consists of, how it is expressed and by which criteria it might be recognized and assessed. It must be mentioned, however, that even in the official Music Curriculum, no criteria, standards or guidelines are specified to music teachers; the only clearly stated expectation is that "assessment criteria must be understood and accepted by all”.

\section{Discussion and Implications for Pedagogy}

The present study sketched a picture of Greek schools' music reality, which differs a lot from what the Music Curricula describe, in relation to the development of creativity in the classroom. The emerging implications of this can be divided in two major areas: one related to teaching and the other related to teachers.

Music creativity may be enhanced only through practice, personal action and pupils' active participation, exploration, experimentation and a "creative dialogue" with the sounds. In this sense, the characterization of the subject of music as a "laboratory" is absolutely correct; Greek reality however belies intentions, as in the majority of schools there is no access to any music rooms, music instruments, technological means etc. The time spent for teaching music in Greek schools, $(20$ - 25 hours per year in secondary, 25 - 30 hours in primary education), is far less than in other European countries. All the above were revealed in this study as factors that inhibit the teaching of creative music activities.

The introduction of teaching materials (student book, workbook and teacher book) in Primary Education seems to have helped teachers. On the contrary, the depreciation of the secondary school textbooks, which have not been revised in the past 20 years, by music teachers, necessitates either the introduction of a new textbook that is in accordance with modern theories and practice of music education, or allowing music teachers to use textbooks of their choice. The recent changes in curricula did not seem to be enough for teachers, who appeared to be frustrated and helpless, especially in secondary education, where they are obliged to teach music without musical instruments, without books, without rooms, in classes of 25 - 30 pupils for 40 
minutes a week.

Teachers are considered to be the most important factor for the development of creativity in education. As analyzed in the introduction of this paper, it is necessary for the educator to be able to recognize, understand and support pupils' creativity, so that s/he teaches accordingly.

The present study demonstrated teachers' difficulties in understanding creativity and most importantly, in distinguishing between creative and non creative elements of teaching. Especially as far as music creativity is concerned, it became evident that teachers may recognize creative activities more through their instinct and common sense than through their knowledge and experience. This resulted in their view that music creativity is something unclear and subjective, an inherent characteristic that cannot be taught, that it does not exist in all pupils and, thus, it is difficult - or even unethical - to assess it.

All music teachers should receive substantial training about creativity in general and music creativity in particular, and they should be provided all the valid methodology and practical advice for its teaching and assessment. Moreover, training should not be offered only to newly appointed teachers, but also to the experienced ones, as years of professional experience appear to be strongly related to the implementation of creative activities.

Finally, the general conclusion of this study is that creativity is considered to be important and desired as a primary aim of music teaching, but at the same time, it is regarded by teachers as something vague, mysterious and personal, thus its enhancement and development without training is almost unfeasible in the current Greek School climate.

\section{REFERENCES}

Amabile, T. M. (1996). Creativity in context: Update to the social psychology of creativity. Oxford: Westview Press.

Belkin, A. (2002). Encouraging musical creativity. URL (last check 3 October 2010).

http://www.musique.umontreal.ca/personnel/Belkin/creativity.htm

Burnard, P. (2006). Reflecting on the creativity agenda in education. Cambridge Journal of Education, 36, 313-318.

doi:10.1080/03057640600865801

Burnard, P., \& Younker, B. A. (2004). Problem-solving and creativity: Insights from students' individual composing pathways. International Journal of Music Education, 22, 59-76.

doi: $10.1177 / 0255761404042375$

Craft, A. (1997). Identity and creativity: Educating teachers for postmodernism? Teacher Development, 1, 83-96. doi:10.1080/13664539700200001

Craft, A. (2005). Creativity in schools: Tensions and dilemmas. London: Routledge. doi:10.4324/9780203357965

Cropley, A. J. (1997). Fostering creativity in the classroom: General principles. In M. A. Runco (Ed.), The creativity research handbook (p. 14). Cresskill, NJ: Hampton Press.

Cropley, A. J. (2001). Creativity in education \& learning: A guide for teachers and educators. New York: Routledge.

Csikszentmihalyi, M. (1996). Creativity: Flow and the psychology of discovery and invention. New York: HarperCollins.

Csikszentmihalyi, M., \& Custodero, L. (2002). Foreword. In T. Sullivan \& L. Willingham (Eds.), Creativity and music education (p. 21). Edmonton: Canadian Music Educators' Association.

Dineen, R., \& Collins, E. (2005). Killing the goose: Conflicts between Pedagogy and politics in the delivery of a creative education. International Journal of Art \& Design Education, 24, 43-52. doi:10.1111/j.1476-8070.2005.00422.x

Elliott, D. J. (1995). Music matters: A new philosophy of music education. New York and Oxford: Oxford University Press.

Gordon, E. (1988). Learning sequences in music: Skill, content, and patterns. Chicago, IL: G.I.A. Publications.

Haroutounian, J. (2002). Kindling the spark: Recognizing and developing musical talent. Oxford and New York: Oxford University Press.

Hickey, M., \& Webster, P. R. (2001). Creative thinking in music. Music Educators Journal, 88, 19-23. doi:10.2307/3399772

Horng, J.-S., Hong, J.-C., ChanLin, L.-J., Chang, S.-H., \& Chu, H.-C. (2005). Creative teachers and creative teaching strategies. International Journal of Consumer Studies, 29, 352-358. doi:10.1111/j.1470-6431.2005.00445.x

Jeffrey, B., \& Craft, A. (2004). Teaching creatively and teaching for creativity: Distinctions and relationships. Educational Studies, 30, 77-87. doi:10.1080/0305569032000159750

Kaufman, J. C., \& Baer, J. (2004). Hawking's haiku, Madonna's math: Why it is hard to be creative in every room of the house. In R. J. Sternberg, E. L. Grigorenko \& J. L. Singer (Eds.), Creativity from potential to realization. Washington DC: American Psychological Association. doi:10.1037/10692-001

Koutsoupidou, T. (2010). Initial music training of generalist kindergarten teachers in Greece: What do they ask for and what do they receive? Arts Education Policy Review, 111, 63-70. doi:10.1080/10632910903455892

Koutsoupidou, T., \& Hargreaves, D. J. (2009). An experimental study of the effects of improvisation on the development of children's creative thinking in music. Psychology of Music, 37, 251-278. doi: $10.1177 / 0305735608097246$

Kratus, J. (1995). A developmental approach to teaching music improvisation. International Journal of Music Education, 26, 27-38.

Lapidaki, E. (2007). Learning from masters of music creativity: Shaping compositional experiences in music education. Philosophy of Music Education Review, 15, 93-117.

doi:10.2979/PME.2007.15.2.93

Lindström, L. (2006). Creativity: What is it? Can you assess it? Can it be taught? International Journal of Art \& Design Education, 25, 5366. doi:10.1111/j.1476-8070.2006.00468.x

Lubart, T. I., \& Guignard, J. H. (2004). The generality-specificity of creativity: A multivariate approach. In R. J. Sternberg, E. L. Grigorenko, \& J. L. Singer (Eds.), Creativity: From potential to realizetion. Washington DC: American Psychological Association. doi: 10.1037/10692-004

Mahboub, K. C., Portillo, M. B., Liu, Y., \& Chandraratna, S. (2004). Measuring and enhancing creativity. European Journal of Engineering Education, 29, 429-436. doi:10.1080/03043790310001658541

National Advisory Committee on Creative and Cultural Education (NACCCE). (1999). All our futures: Creativity, culture \& education. Report to the Secretary of State for Education and Employment, the Secretary of State for Culture, Media and Sport: DfEE.

Odena, O. (2001). How do secondary school music teachers view creativity? A report on educators' views of teaching composing skills. The Annual Conference of the British Educational Research Association.

Odena, O. (2006). Musical creativity and the teacher. An examination of data from an investigation of secondary school music teachers' perceptions of creativity. The 9th International Conference on Music Perception and Cognition, Bologna, 22-26 August 2006, 310-315.

Odena, O., \& Welch, G. (2009). A generative model of teachers' thinking on musical creativity. Psychology of Music, 37, 416-442. doi: $10.1177 / 0305735608100374$

OFSTED. (2003). Expecting the unexpected: Developing creativity in primary and secondary schools. London: Office for Standards in Education.

Reybrouck, M. M. (2006). Musical creativity between symbolic modeling and perceptual constraints: The role of adaptive behaviour and epistemic autonomy. In I. Deliège, \& G. A. Wiggins (Eds.), Musical creativity: Multidisciplinary research in theory and practice (p. 16). Hove: Psychology Press.

Runco, M. A. (2003). Education for creative potential. Scandinavian Journal of Educational Research, 47, 317-324. doi: $10.1080 / 00313830308598$

Runco, M. A. (2006). Creativity is always personal and only sometimes social. In J. A. Schaler (Ed.), Howard Gardner under fire: The rebel psychologist faces his critics (p. 22). Chicago: Open Court. 
Sharp, C. (2004). Developing young children's creativity: What can we learn from research. Topic, 32, 5-12.

Sheridan, M., \& Byrne, C. (2002). Ebb and flow of assessment in music. British Journal of Music Education, 19, 135-143. doi:10.1017/S0265051702000220

Sternberg, R. J. (2003). Creative thinking in the classroom. Scandinavian Journal of Educational Research, 47, 325-338. doi:10.1080/00313830308595

Sternberg, R. J., \& Grigorenko, E. L. (2004). Successful intelligence in the classroom. Theory into Practice, 43, 274-280.

doi:10.1207/s15430421tip4304 5

Sternberg, R. J., Kaufman, J. C., \& Pretz, J. E. (2002). The creativity conundrum: A propulsion model of kinds of creative contributions. New York: Psychology Press.

Swanwick, K. (1979). A basis for music education. Windsor Atlantic Highlands, NJ: NFER.

Tafuri, J. (2006). Processes and teaching strategies in musical improvisation with children. In I. Deliège, \& G. A. Wiggins (Eds.), Musical creativity: Multidisciplinary research in theory and practice (p. 16). Hove: Psychology Press.

Webster, P. R. (1992). Research on creative thinking in music. In R. Colwell (Ed.), Handbook of Research on Music Learning and Tea- ching (pp. 247-265). New York: Shirmer Books.

Webster, P. R. (1994). Measure of creative thinking in music-II (MCTM-II). Administrative guidelines. Chicago, IL: Northwestern University, Unpublished Manuscript.

Webster, P. R. (2002). Creative thinking in music: Advancing a model. In T. Sullivan, \& L. Willingham (Eds.), Creativity and music education (pp. 21). Edmonton: Canadian Music Educators' Association.

Webster, P. R. (2003). Conference feynotes: Asking music students to reflect on their creative work: Encouraging the revision process. $M u-$ sic Education Research, 5, 243-249. doi: $10.1080 / 1461380032000126337$

Wiggins, G. A. (2002). Creative process as meaningful musical thinking. In T. Sullivan, \& L. Willingham (Eds.), Creativity and music education (p. 21). Edmonton: Canadian Music Educators' Association.

Wiggins, J. (1999). Teacher control and creativity. Music Educators Journal, 85, 30-44. doi:10.2307/3399545

Williamon, A., Thomson, S., Lisboa, T., \& Wiffen, C. (2006). Creativity, originality and value in music performance. In I. Deliège \& G. A. Wiggins (Eds.), Musical creativity: Multidisciplinary research in theory and practice (p. 26). Hove: Psychology Press.

YPEPTH. (2003). Cross-thematic curriculum framework for compulsory education. Government Newspaper, 303 \& 304, 13 March 2003 